Tyndale Bulletin 66.2 (2015) 271-292

\title{
INFANT BAPTISM IN THE FIRST-CENTURY PRESUPPOSITION POOL ${ }^{1}$
}

\author{
Steven A. Nicoletti \\ (stevennicoletti@gmail.com)
}

\begin{abstract}
Summary
The debate over infant baptism in the apostolic church was classically captured in the exchanges between Joachim Jeremias and Kurt Aland. Most debates have focussed on 'reading between the lines' of firstcentury Christian texts, and have yielded little resolution of the New Testament's silence. Such studies often fail to address the significance of the silence itself, within its original context. In this paper I examine the practices of first-century Judaism and Graeco-Roman religions regarding infant initiation and participation in their parents' religion, including the Graeco-Roman practice of the dies lustricus and the involvement of children in Graeco-Roman worship. Using Theo Vennemann's concept of presupposition pools, I will ask how the early church's silence should be interpreted in light of the original audiences' presuppositions. I will argue that since the New Testament and other surviving works of the early church do not address their audiences' presupposition that their infants would be initiated into their religion, it indicates that they shared rather than challenged this widely held assumption. The New Testament's silence is therefore best interpreted as indicating the practice of infant baptism.
\end{abstract}

\section{Introduction}

Cambridge professor C. F. D. Moule said of Joachim Jeremias's 1958 book Infant Baptism that it contained 'at least' all the evidence in favor

1 I am grateful to Michael Farley, C. John Collins, Robert W. Yarbrough, and David W. Chapman for their conversations and comments, which helped clarify my thinking and pointed me to several helpful resources. 
of the apostolic origin of infant baptism. ${ }^{2}$ And indeed, in the last fifty years we have not stumbled upon any new direct evidence of the apostolic practice in this period. However, in his 2004 paper 'Did the Apostolic Church Baptise Babies?: A Seismological Approach', Anthony N. S. Lane proposed an alternative to what he called the tendency "to torture the early evidence in order to make it say more than the authors intended, to read between the lines of first-century documents'. Instead of examining the data (or lack thereof) from the church in the first century, he examined the data from the church in the early patristic period, and its relationship to the apostolic church. From this examination he drew his conclusions on what 'must have happened in apostolic times' to explain the later practices. ${ }^{3}$

Rather than look at the direct data, which is scant, Lane looked at data from a related time and place, and drew conclusions from it to the apostolic period. This paper will seek to follow that same approach, but in a different direction, thus supplementing Lane's work.

Our goal here will be to examine how the apostolic church's silence on the topic of infant baptism should be interpreted in light of the presuppositions of the New Testament's original audiences: particularly new converts to the church from first-century Judaism or Graeco-Roman religion. What we will find is that the practice that best fits with this data is that the apostolic church fully initiated the infants of Christians into the church through baptism.

\section{Presupposition Pools in Meaning, Silence, and Infant Baptism}

\subsection{Presupposition Pools and Meaning}

In a 1975 essay, Theo Vennemann argued that in discourse, presuppositions are carried not in the structure of the discourse itself, but in a 'presupposition pool'. He explained that 'the information contained in this pool is constituted from general knowledge, from the situative context of the discourse, and from the completed part of the

2 David F. Wright, 'Out, In, Out: Jesus' Blessing of the Children and Infant Baptism', in Dimensions of Baptism: Biblical and Theological Studies, ed. Stanley E. Porter and Anthony R. Cross (London: Sheffield Academic, 2002), 188-206, esp. 192.

3 Anthony N. S. Lane, 'Did the Apostolic Church Baptise Babies?: A Seismological Approach', TynBul 55.1 (2004), 109-30, esp. 109-10. 
discourse itself' ${ }^{4}$ Peter Cotterell and Max Turner have elaborated on this concept to show that the true meaning of a piece of discourse can vary greatly depending on our understanding of its presupposition pool..$^{5}$

\subsection{Presupposition Pools and Silence}

In their discussions of presupposition pools, neither Vennemann nor Cotterell and Turner directly address how silence on a relevant topic should be interpreted within the context of a presupposition pool, but Vennemann does give us the concepts to begin considering the question. Vennemann explains that a participant's presupposition pool

can be characterized as the set of all assumptions relevant to the discourse which he believes are shared by all the participants. At least this is so in a normal, honest discourse. A discourse can continue undisturbed as long as the assumption of the shared presupposition pool can be entertained. As soon as the participants notice that this assumption is wrong, the discourse - or a particular portion of the discourse - ends, and a discussion of the discrepant presuppositions begins ... during which no participant entertains the discrepant presuppositions as presuppositions. ${ }^{6}$

If author and audience share a presupposition relevant to their discourse, there is essentially no need to discuss it explicitly. It is only when the author and audience find a discrepancy in their presuppositions that the issues they presupposed must be taken out of the unspoken presupposition pool and discussed explicitly as topics themselves.

An example may be helpful. The Declaration of Independence of the United States of America nowhere explicitly mentions the topic of the enslaved Africans in the USA. That fact by itself may initially lead someone to say that the document is unclear on its position regarding slavery. Moreover, by looking at the document itself, some may see statements that, though they do not explicitly mention slavery, appear to a twenty-first-century American reader to imply opposition to the institution. This would include statements like 'all men are created

4 Theo Vennemann, 'Topics, Sentence Accent, Ellipsis: A Proposal for Their Formal Treatment', in Formal Semantics of Natural Language: Papers from a Colloquium Sponsored by the King's College Research Centre, Cambridge, ed. Edward L. Keenan (Cambridge: CUP, 1975), 313-28, esp. 314.

5 Peter Cotterell and Max Turner, Linguistics and Biblical Interpretation (Downers Grove, IL: InterVarsity, 1989), 90-97.

6 Vennemann, ‘Topics, Sentence Accent, Ellipsis', esp. 314. 
equal', and that such men have rights to 'Life, Liberty and the pursuit of Happiness'. And yet, one would be wrong in drawing the conclusion from this passage that the document opposes the institution of slavery. The document's actual views on slavery are learned not from the document itself, but from the original presupposition pool within which it was written and read. Once we realise that the document was originally sent from colonies in which slavery was legal, to a country in which slavery was legal, and that its primary author himself owned over 185 slaves at the time of writing, ${ }^{7}$ we see that in its original role as a piece of discourse, the statement that 'all men are created equal' was not originally intended to contradict the practice of racially based slavery. Again, this realisation is only reached by a historical knowledge of the presupposition pool - and cannot be deduced from the discourse itself.

There are two key concepts seen in this example. The first is that because the author and audience share presuppositions about racebased slavery in their presupposition pool, the topic itself need not explicitly come up, even when topics relevant to it (such as equality and freedom) are being discussed. The second key concept is that the position of the author and audience on the relevant topic is neither found in nor deduced from the discourse itself, but from a historical investigation of the presupposition pool of the discourse.

\subsection{The Silence On Infant Baptism in the New Testament and Other Early Documents}

For the sake of this paper we will grant that neither the New Testament nor any other Christian document from the first two centuries explicitly deals with the topic of infant baptism. The question is what conclusions we can or should draw from this silence.

We must first be very wary of any interpretation of this silence that simplistically jumps to a conclusion that the first-century church must not have practised infant baptism. Such arguments may point to New Testament statements about baptism that we do not imagine could apply to an infant. But to adopt that line of argument too hastily would make us like the young student, arguing with his history teacher that Thomas Jefferson could not have owned slaves because of the words he

7 Edmund S. Morgan, American Slavery, American Freedom (New York: Norton, 1975), 4. 
penned in the Declaration of Independence. Such a student reads an old document with his twenty-first-century presupposition pool. We must beware of doing the same.

A better interpretive step would be to consider that the silence indicates that there was no disagreement about the place of infants born to Christians within the church. The authors of the New Testament exhibit little interest in explicitly discussing the topic of infant initiation into the faith, whether addressing churches consisting of converts from Judaism or from Graeco-Roman religion. The book of Acts records no open discussion of the topic of what to do with the infants of believers, either when large numbers of Jews (for example in Acts 2) or large numbers of Gentiles (for example in Acts 10) were converted and joined the faith. The same is true of documents that have survived from the second century. All appear to be silent.

And yet the early church had to have done something with the infants of Christians and new converts. Whether they baptised and fully initiated them, treated them as outsiders until they matured, or did something in between, from the day of Pentecost on, ${ }^{8}$ the church had to do something with these infants. And so rather than telling us what exactly the church did with their infants, the New Testament's silence and the silence of the church in the first two centuries instead indicates a lack of a dispute over what to do with the infants of Christians. This lack of a dispute, and the lack of explicit instruction, suggests that the authors of these documents believed they shared presuppositions with their audience about how infants related to their parents' religion, whether their audience were converts from Judaism or Graeco-Roman religion.

And so the fact that the topic of an infant's place in the religion did not surface explicitly most likely indicates shared and undisputed presuppositions on the topic between the Christian authors and the world around them for whom they were writing. If that is true, then one constructive way to begin to discern the authors' views and the practices of the early church regarding infants is to investigate the presuppositions of the Jewish and the Graeco-Roman world around the church, regarding the religious standing of infants. From there we can infer the most likely meaning of the fact that the New Testament

8 Lane, 'Did the Apostolic Church Baptise Babies?', 111. 
authors do not dispute those views, but leave them silently submerged in the presupposition pool of their audience.

\section{Baptism and Initiation: Moving from Form to Function}

Before we begin our historical investigation, a final task remains. One issue that has hampered studies of infant baptism has been a fixation on the form of water baptism rather than its function. Often the discussion on the context and history of Christian baptism is limited to Jewish and Graeco-Roman water rites, rather than focused on Jewish and GraecoRoman rites that performed a similar function in their contexts to baptism performed within the church.

While the New Testament speaks of baptism in many ways, ${ }^{9}$ we will focus on baptism as that which initiates an individual into 1) the Christian church, and 2) the Christian life. In other words, we will focus on baptism's function as a rite that moves one from outside the church community to inside the church as a full member, and that marked the formal beginning of an individual's life as a Christian, as one 'in Christ'. Baptism may be more than just an initiation rite, but it certainly is not less. For our purposes, we will focus on this initiatory function.

Within the apostolic ministry, as described by the New Testament, baptism and Christian initiation are synonymous. Wayne A. Meeks points out that the church made baptism 'bear the whole function of initiation', which was 'the decisive point of entry into an exclusive community'. ${ }^{10}$ Adela Yarbro Collins, ${ }^{11}$ Maxwell E. Johnson, ${ }^{12}$ and Aidan Kavanagh ${ }^{13}$ have similarly argued that in the early church, water baptism served as a rite of initiation into the Christian faith and community. The book of Acts puts forward a similar picture. Whatever

\footnotetext{
9 Maxwell E. Johnson, The Rites of Christian Initiation: Their Evolution and Interpretation, revised and expanded ed. (Collegeville, MN: Liturgical, 2007), 37-39.

10 Wayne A. Meeks, The First Urban Christians: The Social World of the Apostle Paul (New Haven, CT: Yale, 1983), 152-53.

11 Adela Yarbro Collins, 'The Origin of Christian Baptism', in Living Water Sealing Spirit: Readings on Christian Initiation, ed. Maxwell E. Johnson (Collegeville, MN: Liturgical, 1995), 35-57, esp. 51-53.

12 Johnson, The Rites of Christian Initiation, 23.

13 Aidan Kavanagh, The Shape of Baptism (Collegeville, MN: Liturgical, 1991), $20-23$.
} 
variation occurs in Acts regarding how the church initiated people into the community and its faith, one of the consistent aspects (when that ritual process is described in any detail) is that they are baptised. ${ }^{14}$ The form of Christian baptism accomplished the function of Christian initiation.

For the rest of this paper, we will focus on this function rather than the details of the form. This will allow us to more accurately compare practices between religions, focussing not on what they look like, but what function they perform within the religion. With that view in mind, we will examine the first-century presuppositions regarding infant initiation in both Judaism and Graeco-Roman religions, and then we will consider their implications for the practices of the first-century church.

\section{First-Century Presuppositions Regarding Infant Initiation into Judaism}

\subsection{Initiation at Eight Days}

In the Jewish Scriptures, initiation into the covenant of Abraham and the promises it entailed was accomplished by circumcision of all males (Gen. 17), upon conversion for those born outside of the community (Exod. 12:48), or on the eighth day after birth for those born within the community (Gen. 17:12; 21:4; Lev. 12:1-3). Circumcision made one like a 'native of the land' within Israel, and therefore eligible to participate in the religious life of the community (Exod. 12:43-49). There is no additional initiation rite or process given in the Jewish Scriptures. Instead, full initiation is accomplished when an infant is only eight days old. For females in the community, no rite is given at eight days, but neither is there a later rite. Since there is a clear demarcation between women in the community and women outside the community (see Deut. 7:3; Neh. 10:30; 13:25), the assumption seems to be that women born within the community are considered full initiated members at birth, without such a rite. The New Testament records the circumcisions of John the Baptist (Luke 1:59) and Jesus (Luke 2:21), each on the eighth day after their birth, suggesting that

14 E.g. Acts $2: 37-41 ; 8: 12,35-39 ; 9: 17-19 ; 10: 44-48 ; 16: 13-15,30-34 ; 18: 8 ; 19: 1-7$; 22:12-16. 
infant initiation through circumcision continued to be normative in the first century.

\subsection{First-Century Bar Mitzvahs?}

While the celebration of Bar Mitzvah has become popular in modern times, there is no evidence that this Jewish rite for males crossing from boyhood to adulthood (at age 13) occurred in the first century. Instead, the term is not used to describe such a ceremonial occasion until the fifteenth century AD. Though before this period (even as early as the second century $\mathrm{AD}$ ) we do see concepts of male adulthood beginning at age 13, this change was primarily a legal one, in which the individual was responsible for his own actions (rather than his father being responsible) and in which one was able to make legally binding vows. While the transition to adulthood at age 13 may have meant an increase in certain religious obligations (as the completion of a process described below), it did not mark a change in the individual's religious access. It was not viewed as an initiation into the religious community (as if they were not already members), nor was it accompanied by any type of rite at this time..$^{15}$

\subsection{Infant Participation in Jewish Religious Life in the First Century}

The Mishnah gives us a further glimpse into Jewish thought on infant initiation in the early centuries AD. While the Mishnah was compiled in its current form around AD 200, ${ }^{16}$ much work has been done to try to determine which portions of the text originated in which rabbinic period. We will draw below on such efforts by Jacob Neusner.

What we find in the Mishnah is that infants were considered fully initiated into the Jewish religion from infancy, and were only hindered from participating in the religious life of the community to the extent that they were physically unable to do so. Hagigah 1:1 discusses at what age a boy was obligated to travel to Jerusalem to take part in the three annual feasts. After indicating that a child is not obligated to appear at the temple for the festivals, the text asks 'Who is deemed a child?' It goes on to answer, 'Any that cannot ride on his father's

15 Norman Baumel Joseph, 'Bar Mitzvah, Bat Mitzvah', in Encyclopaedia Judaica, ed. Fred Skolnik and Michael Berenbaum, 2nd ed. (Detroit, MI: Macmillan, 2007), 3:164-67.

16 Jacob Neusner, Rabbinic Literature: An Essential Guide (Nashville, TN: Abingdon, 2005), 19. 
shoulders and go up from Jerusalem to the Temple Mount. So the School of Shammai. And the School of Hillel say: Any that cannot hold his father's hand and go up [on his feet] from Jerusalem to the Temple Mount.' ${ }^{17}$ We will first consider the implications of the text itself, and then its dating.

There are two important things to note from this text. First is that there appears to be no further initiation before these boys could participate in the full religious life of Israel. Second, the discussion is not about who is permitted to participate in the annual feasts in Jerusalem, but who is required to participate. There is no minimum age for participation here, but (at the least) all boys old enough to walk well were required to take part in the feasts in Jerusalem. It seems to be assumed that anyone fully initiated into the Jewish faith (usually from the eighth day after birth) was permitted to participate in these feasts (assuming they met the requirements for ceremonial cleanness). ${ }^{18}$ The Jews who compiled this portion of the Mishnah considered children to be initiated from infancy, participating as they were able. But when was this text compiled?

There are multiple reasons to conclude that this passage from Hagigah 1:1 reflects first-century Jewish views and practices. We can begin with a simple surface level reading of the text itself. The text purports to record the views of two houses, the Houses of Hillel and Shammai. These two schools of Jewish theology and rabbinic interpretation existed from the end of the first century $\mathrm{BC}$ until the beginning of the second century $\mathrm{AD}$, but their debates primarily occurred during the last two to three generations of the Second Temple period. ${ }^{19}$ In addition to that, this text appears to presuppose the

17 The Mishnah, trans. Herbert Danby (New York: OUP, 1974), 211.

18 This has relevance for modern debates about paedocommunion. Jews at the time when the Eucharist was instituted expected all boys old enough to walk to be required to participate in the Passover and other annual feasts. This information stands against assertions by some that participation in the Passover was limited to an 'age of discretion' at 20 or 13 (e.g. Cornelis P. Venema, Children at the Lord's Table? [Grand Rapids, MI: Reformation Heritage, 2009], 67). As a result, a position that claims that (with no direct writing on the subject) the apostolic church barred all children not old enough to make a 'credible profession of faith' from the Eucharist faces an uphill battle when the institution of the Eucharist is considered in its own historical context rather than ours. Barring young children from participating in such a meal would appear to be a foreign concept to a first-century Jew.

19 Shmuel Safrai, 'Bet Hillel and Bet Shammai', in Encyclopaedia Judaica, ed. Fred Skolnik and Michael Berenbaum, 2nd ed. (Detroit, MI: Macmillan, 2007), 3:530-33, esp. 3:530. 
existence of the temple, which was destroyed in AD 70. With this surface level reading, we would assume that the text provides a window into the dominant rabbinic views within the Jewish community at the time of the apostolic church.

Of course we must make a somewhat more rigorous evaluation of the origin of this text, and consider that it could be a later set of views attributed to earlier rabbinic schools. Following the methodology of Jacob Neusner we will find that Hagigah 1:1 most likely comes from the Yavneh period of the formation of the Mishnah, which is the earliest layer of compiling, and the most likely to represent an accurate view of first-century Judaism.

Yavneh became the center of Jewish self-government and religious learning after $\mathrm{AD} 70$, and it continued to fill this role until about $\mathrm{AD}$ $135 .{ }^{20}$ Yavneh maintained a higher level of continuity with pre-AD-70 Judaism, while the real break in rabbinic thought came in AD 140, after the Bar Kokhba revolt was put down by Rome. ${ }^{21}$ Therefore, according to Neusner, verifying that a text is from the Yavneh period is extremely important in estimating the traditions of the Pharisees by the end of the first century. ${ }^{22}$ Hagigah 1:1 can best be dated to the early Yavneh period because of its form, external verifications, style, and the nature of its question.

First, Hagigah 1:1 most likely dates to the early Yavneh period because of its form, in which the opinions of the House of Shammai and the House of Hillel are placed side by side, on equal footing. Neusner argues that texts in this form come from a period when the two Houses were of roughly equal strength, a situation only found in the early Yavneh period. ${ }^{23}$

The second factor in dating this passage is its external verification. Based on parallel or similar passages in Mekhilta de Rabbi Simeon ben Yohai and Sifre to Deuteronomy, Neusner concludes that Hagigah 1:1 likely reached its current form during the Yavneh period. ${ }^{24}$

20 H. L. Strack and G. Stemberger, Introduction to the Talmud and Midrash, trans. Markus Bockmuehl (Minneapolis, MN: Fortress, 1992), 2.

21 Jacob Neusner, The Rabbinic Traditions About the Pharisees Before 70 (Leiden: Brill, 1971), 3:283; Strack and Stemberger, Introduction, 5.

22 Neusner, Rabbinic Traditions, 3:224.

23 Neusner, Rabbinic Traditions, 3:315.

24 Neusner, Rabbinic Traditions, 3:207. 
The third factor in dating is style. Based on assigning a terser, formulaic style aimed at memorisation to the early Yavneh texts, Neusner assigns our text dealing with children making pilgrimage to the House-traditions that were known by about AD 100-120. ${ }^{25}$

Finally, an early date can be attributed to Hagigah 1:1 because its question is ultimately priestly and not rabbinic. Temple regulations before AD 70 could be found out, authoritatively, by simply asking any temple priest. Since the temple regulations in the Mishnah do not seem to communicate an underlying theme, ${ }^{26}$ it is likely that rather than being an actual dispute, our text simply contains two different ways in which the Houses recorded temple regulations as given by the priests. ${ }^{27}$ This would give the content of the pericope a root in the first century. All of the above factors support the idea that Hagigah 1:1 describes first-century practices and views.

A corresponding text in the Tosefta (a supplement to the Mishnah compiled closer to AD 300 ${ }^{28}$ lends support to our interpretation of Hagigah 1:1 of the Mishnah. Hagigah 1:2 of the Tosefta discusses the religious obligations of children, stating '[If] he knows how to shake [an object], he is liable to observe the commandment of the lulab. [If] he knows how to cloak himself, he is liable for the commandment of fringes.' ${ }^{29}$ The text goes on to elaborate a system where a child becomes obligated to certain religious practices at the stage where he is physically able to participate. As with the Mishnah, the underlying principle is that a child is fully initiated as a newborn and takes on religious responsibilities as he is able - not in a later rite of initiation. ${ }^{30}$ This would be the presupposition of those coming out of Judaism and into the early church.

\footnotetext{
25 Neusner, Rabbinic Traditions, 3:223-25.

26 Neusner, Rabbinic Traditions, 3:228.

27 That our text appears to present a dispute between the Houses on this matter may seem to undercut this claim. But Neusner elsewhere points out that the dispute form is just that - a form. Neusner assumes that the individual Houses kept independent records of their own opinions. It was only later when the Shammai-Hillel-Housescorpus was assembled that it was all put into the form of the dispute - whether a real disagreement existed or not (Rabbinic Traditions, 3:317).

28 Neusner, Rabbinic Literature, 31.

29 The Tosefta, trans. Jacob Neusner (Peabody, MA: Hendrickson Publishers, 2002), 1:663-64.

30 While Hagigah 1:3 of the Tosefta discusses puberty, this passage marks the end of the progressive ability-based participation in religious life, not the beginning. A Jewish child was not initiated into religious life at puberty, but their progressive participation in religious life must be completed by puberty.
} 


\subsection{First-Century Jewish Proselyte Baptism?}

In his classic work arguing for the New Testament origin of infant baptism, Joachim Jeremias contends that Jewish proselyte baptism shaped the first-century church's understanding of Christian baptism, including its relationship to infants. ${ }^{31}$ To evaluate this claim we must ask two questions: first, if first-century Jewish converts to Christianity were familiar with proselyte baptism, how would it affect their presuppositions regarding infant initiation? Second, do we have sufficient evidence to support the claim that Jewish proselyte baptism was practiced in the period of the apostolic church?

Regarding how proselyte baptism related to the infants of converts to Judaism in the first century, Jeremias argues that since 'the oldest rabbinic sources' that address the topic 'take it completely for granted' that the children of converts would be baptised along with their parents, we can assume that this was the common practice. ${ }^{32}$ However Jeremias himself acknowledges that the earliest direct references to proselyte baptism being administered to infants originate between the end of the third and the middle of the fourth centuries AD. ${ }^{33}$ This leaves us with a long period of initial silence regarding proselyte infant baptism, in a pattern of data not unlike that which we have regarding Christian infant baptism, though our first direct reference to Christian infant baptism actually comes earlier (early in the third century). ${ }^{34}$ While several scholars have agreed that administering proselyte baptism to the infants of converts was likely to have been the norm, ${ }^{35}$ the late date of our first direct reference to the practice should make us hesitant to draw too strong a conclusion about how Jewish proselyte baptismal practices might have shaped first-century presuppositions regarding infant initiation.

This leads us to our second question: do we have sufficient evidence to support the claim that Jewish proselyte baptism was being practiced in the period of the apostolic church? Jeremias argues that we do,

\footnotetext{
31 Joachim Jeremias, Infant Baptism in the First Four Centuries, trans. David Cairns (Eugene, OR: Wipf \& Stock, 1960), 24-40.

32 Jeremias, Infant Baptism, 39.

33 Jeremias, Infant Baptism, 38-39.

34 Lane, 'Did the Apostolic Church Baptise Babies?', 120.

35 Everett Ferguson, Baptism in the Early Church: History, Theology, and Liturgy in the First Five Centuries (Grand Rapids, MI: Eerdmans, 2009), 81; G. R. BeasleyMurray, Baptism in the New Testament (Eugene, OR: Wipf \& Stock, 1972), 329.
} 
pointing to what he believes is a reference to proselyte baptism in a dispute between the houses of Shammai and Hillel recorded in both the Mishnah (Pesahim 8:8) and the Tosefta (Pesahim 7:14). He also relies on the claim that Jews began to consider Gentiles ritually impure in the first century $\mathrm{BC},{ }^{36}$ making such a washing necessary at conversion. Recent scholarship, however, has thrown both of these claims into question. In her monograph on the subject, Christine Hayes argues that the rabbinic ascription of ritual impurity to Gentiles originated in the first two centuries $\mathrm{AD},{ }^{37}$ and not the first century $\mathrm{BC}$ as Jeremias claims. If correct, this would eliminate the need for a washing to remove Gentile impurity in the first half of the first century AD.

Shaye J. D. Cohen has argued persuasively that interpreting the immersion mentioned by the House of Shammai in m. Pesahim 8:8 and t. Pesahim $7: 14$ as proselyte baptism 'is almost certainly wrong', ${ }^{38}$ explaining that in both texts the immersion is presented as something to be done in preparation for the Passover, after conversion is complete, and not as a part of the conversion process itself. ${ }^{39}$ Agreeing with Cohen's work, Hayes points out that in the Mishnah's account, the immersion prescribed for the new convert before the Passover is presented as a parallel to the immersion prescribed to a bereaved Jew before the Passover. She also argues that the immersion described by these two texts is not done to remove impurity, but to bestow sanctity before one consumes the Passover. ${ }^{40}$

If Cohen is correct, then the earliest explicit reference we have to proselyte baptism dates from the late first or early second century AD, and it describes how even though proselyte baptism was being recognised as an essential part of conversion by some authorities by

36 Jeremias, Infant Baptism, 24-29.

37 Christine E. Hayes, Gentile Impurities and Jewish Identities: Intermarriage and Conversion from the Bible to the Talmud (Oxford: OUP, 2002), 123, 142.

38 Shaye J. D. Cohen, 'Is "Proselyte Baptism" Mentioned in the Mishnah? The Interpretation of m. Pesahim 8.8 (=m. Eduyot 5.2)', in Pursuing the Text: Studies in Honor of Ben Zion Wacholder on the Occasion of his Seventieth Birthday, ed. John C. Reeves and John Kampen (Sheffield: Sheffield Academic, 1994), 278-92, esp. 281-82. Ferguson agrees (Ferguson, Baptism in the Early Church, 77).

39 Cohen, 'Proselyte Baptism', 290.

40 Hayes, Gentile Impurities, 116-22, 214; Christine Hayes, 'Do Converts to Judaism Require Purification?: M. Pes 8:8 - An Interpretive Crux Solved', Jewish Studies Quarterly 9 (2009), 327-52. 
that time, it was not being viewed as such by all. ${ }^{41}$ While some have argued that the establishment of proselyte baptism must have preceded the emergence of Christian baptism because the Jews would not have adopted a practice that may have been viewed by many as a Christian custom, ${ }^{42}$ others have pointed out that this argument fails to recognise 1) the reality that Judaism had a number of washing rituals from which proselyte baptism could have been derived, ${ }^{43}$ 2) the possibility that, rather than one deriving from the other, proselyte baptism and Christian baptism may share some features because they both developed out of the same historical and cultural context, ${ }^{44}$ and 3) the fact that there are actually many differences between the administration of proselyte baptism and Christian baptism. ${ }^{45}$

After considering the data, and in light of recent scholarship, it seems that we have insufficient evidence to either claim that proselyte baptism shaped Jewish presuppositions regarding infant initiation in the period of the apostolic church, or to know with confidence how it would have shaped those presuppositions if it was being practiced at the time. Circumcision and infant participation in Jewish religious life are therefore likely to be our most reliable indicators of Jewish expectations regarding infant initiation in the first century.

\section{First-Century Presuppositions Regarding Infant Initiation into Graeco-Roman Religions}

We have seen above, from our study of circumcision and infant participation in Jewish religious life, that first-century Jews would have assumed that their infants would be fully initiated into their faith, and could participate in religious life with no further initiation rites required. However the early church quickly saw a large influx of

41 Collins, 'The Origin of Christian Baptism', 44-45; Ferguson, Baptism in the Early Church, 78, 80.

42 Albrecht Oepke, 'baptō', TDNT 1:529-46, esp. 1:535; Jeremias, Infant Baptism, 24, 29.

43 Ferguson, Baptism in the Early Church, 79. Several possibilities have been suggested (e.g. Hayes, Gentile Impurities, 214; Cohen, 'Proselyte Baptism', 282, 291; Collins, 'The Origin of Christian Baptism', 44; Ferguson, Baptism in the Early Church, 78).

44 Johnson, The Rites of Christian Initiation, 10.

45 Ferguson, Baptism in the Early Church, 81-82, contra. Jeremias, Infant Baptism, 29-37. 
Gentiles into its ranks. What presuppositions would these Gentiles have brought with them about infant participation in religion?

\subsection{Dies Lustricus}

An important ceremony in the life of a Graeco-Roman infant was the dies lustricus. This ceremony focused on naming the infant, ritually purifying it, and formally admitting and welcoming it into the family. ${ }^{46}$ It was through this rite that infants entered into social life. They were only recognised by the state after this rite and, in a sense, they did not exist in society until this rite was performed. This ceremony, in a very real way, was the infant's 'social birth'. The ceremony occurred on the ninth day after birth for boys and the eighth day after birth for girls. ${ }^{47}$ Scholars vary in their assessment of how well we can reconstruct this rite. While some have attempted a more elaborate reconstruction of the ritual, ${ }^{48}$ Véronique Dasen has argued more conservatively that the main things we can know are that the dies lustricus events included sacrifices, purifications, and a family gathering. ${ }^{49}$ In any case, the focus of the dies lustricus was on the naming of the infant, the beginning of its participation in the state, and its welcoming into the family.

Scholars identify the dies lustricus as a practice of Roman antiquity. ${ }^{50}$ Primary source references to it are scattered, and range in

46 Beryl Rawson, 'Adult-Child Relationships in Roman Society', in Marriage, Divorce, and Children in Ancient Rome, ed. Beryl Rawson (New York: OUP, 1991), 7-30, esp. 14; Marja-Leena Hänninen, 'From Womb to Family: Rituals and Social Conventions Connected to Roman Birth', in Hoping for Continuity: Childhood, Education and Death in Antiquity and the Middle Ages, ed. Katariina Mustakallio et al., Acta Instituti Romani Finlandiae 33 (Tampere: Tammer-Paino Oy, 2005), 49-59, esp. 57; Peter Garnsey, 'Child Rearing in Ancient Italy', in The Family in Italy: From Antiquity to the Present, ed. David I. Kertzer and Richard P. Saller (New Haven, CT: Yale University Press, 1991), 48-65, esp. 53.

47 Christian Laes, Children in the Roman Empire: Outsiders Within (New York: CUP, 2011), 65-66.

48 Laes, Children, 66-67. Laes seems to draw on ritual descriptions provided by Augustine, on the basis of Varro (Augustine, City of God, VI.9), but the historical accuracy of Augustine's description of this rite is questionable (Hänninen, 'From Womb to Family', 56).

49 Véronique Dasen, 'Roman Birth Rites of Passage Revisited', Journal of Roman Archaeology 22 (2009), 199-214, esp. 207.

50 E.g. Laes, Children, 66-67; Rawson, 'Adult-Child Relationships', 16; Jens-Uwe Krause, 'Children in the Roman Family and Beyond', in The Oxford Handbook of Social Relations in the Roman World, ed. Michael Peachin (New York: OUP, 2011), 623-42, esp. 627; W. Warde Fowler, The Religious Experience of the Roman People, From the Earliest Times to the Age of Augustus (New York: Cooper Square, 1971), 28; 
specificity. Christian Laes gives a variety of primary source references, spanning a period from the fourth century BC to the fourth century AD, and spread across a geographical area including Rome, Greece, and Africa. ${ }^{51}$

What is important for us to note is that since both the state and the family were cultic and religious in nature, the dies lustricus cannot be thought of as merely a secular-social initiation, but must be considered a religious initiation as well. Even if the emphasis of the ritual was often on its social aspects, the dies lustricus still accomplished the function of initiating infants into the religious and cultic life of the state and family.

Dasen has pointed out that many questions remain about the dies lustricus. One is whether non-Roman citizens, such as slaves, would have also performed this rite for their infants. At this point the answer is uncertain, though Dasen believes there are hints that they may have. ${ }^{52}$ Further research is clearly needed, but as the data stands it seems most likely that some form of the dies lustricus was performed for all infants accepted into their families.

What is important to note here is that this ceremony, intended to be performed on newborns in the Graeco-Roman world, was religious in nature (likely including sacrifices and purifications) and had the intention of initiating the infant into family and state life, both of which were cultic and religious.

\subsection{Further Initiation?}

If the dies lustricus was a rite of initiation into the cultic community of the family and the state, was it the only initiatory rite, or were there other standard initiation rites in the life of a child growing to adulthood? While the end of infancy was seen as coming at age seven, there was no rite of passage or initiation at this age..$^{53} \mathrm{~A}$ boy's transition into manhood was marked by a special ceremony in wealthy families, where garments of childhood were exchanged for garments of

W. A. Strange, Children in the Early Church: Children in the Ancient World, the New Testament and the Early Church (Eugene, OR: Wipf \& Stock, 2004), 3.

51 Laes, Children, 66.

52 Dasen, 'Roman Birth Rites', 208.

53 Laes, Children, 84. 
manhood, ${ }^{54}$ but this ceremony did not seem to carry a function of religious initiation or add religious privileges or responsibilities.

As such, the dies lustricus appears to have functioned in Roman life as the sole rite of initiation into the state and family, as well as the cultic life associated with each. No further initiation seems to have been carried out, at least in any standardised way.

\subsection{Child Participation in Graeco-Roman Religions}

The Graeco-Roman world had not one religion but many cultic societies that overlapped. Those societies fit into three major categories which we will examine below: 1) the civic and imperial cult, 2) the family cult, and 3 ) voluntary associations and cults. ${ }^{55}$

\section{a. The Civic and Imperial Cult}

It is important to remember that religion was a state affair. As such, each city (and often even neighbourhoods within a city) had a civic religion - a specific set of gods that made up the pantheon of that particular city. Additionally, the empire also had its own cult that spread everywhere its power went, and included worship of the emperor. ${ }^{56}$

The evidence suggests that young children participated in these civic cults. Young boys (not yet of age) would assist the priests in cultic worship, serving as acolytes and participating in the sacrifices. ${ }^{57}$ Children sang in religious state festivals, ${ }^{58}$ and at times girls assisted in rituals of expiation. ${ }^{59}$ Dionysius describes some public ceremonies which men were forbidden to celebrate and which only women and children could participate in. Children's assistance in the rituals of the civic cults was apparently seen as analogous to their assistance in the

54 Rawson, 'Adult-Child Relationships', 27-28; Laes, Children, 279-80; Krause, 'Children', 629.

55 John Scheid, 'Graeco-Roman Cultic Societies', in The Oxford Handbook of Social Relations in the Roman World, ed. Michael Peachin (New York: OUP, 2011), 535-47.

56 Scheid, 'Graeco-Roman Cultic Societies', 537-41.

57 Scheid, 'Graeco-Roman Cultic Societies', 538; O. M. Bakke, When Children Became People: The Birth of Childhood in Early Christianity, trans. Brian McNeil (Minneapolis, MN: Fortress, 2005), 49-50; I. C. Mantle, 'The Roles of Children in Roman Religion', in Greece \& Rome 49, no. 1 (April 2002), 85-106, esp. 91-99.

58 Thomas Wiedemann, Adults and Children in the Roman Empire (New Haven, CT: Yale University Press, 1989), 182; Mantle, 'Roles of Children in Roman Religion', 8691.

59 Mantle, 'Roles of Children in Roman Religion', 89. 
family cult (see below). ${ }^{60} \mathrm{I}$. C. Mantle also points to several pieces of art from outside of Rome that provide visual evidence of children assisting in the worship of the civic and imperial cults. ${ }^{61}$

It therefore appears that young children participated in the civic and imperial cults, which would have been an inherent aspect of being part of the Roman state. Their official recognition as members of the state was achieved at their dies lustricus, and the religious acts associated with membership were taken up in ways appropriate to the child's age, as they developed.

\section{b. The Family Cult}

Each family also had its own unique family religion, which was created by their ancestors and included all members of the family. ${ }^{62}$ Religious rites were a core part of family life, and those rites had specific responsibilities for children. ${ }^{63}$ Young children had special roles in which they assisted in family ceremonies, such as throwing grain or slices of honeycomb into the sacrificial fire. ${ }^{64}$ As with the civic and imperial cult, it appears that children participated in the family cult, with no further initiation. As the dies lustricus gave the child a name and socially 'birthed' them into the family, that 'birth' would have also initiated them into the family cult.

\section{c. Voluntary Assemblies and Cults}

The role of children in voluntary religious assemblies is less clear than it is in civic and family cults. Examples of child participation do exist in the cultic practices associated with Dionysus, ${ }^{65}$ the Eleusinian Mysteries, ${ }^{66}$ and other ancient sanctuaries. ${ }^{67}$ On the other hand, since many voluntary assemblies and cults were associated with various trades, it is also apparent that many of these groups did not initiate

60 Wiedemann, Adults and Children, 183-84.

61 I. C. Mantle, 'Addendum: The Religious Roles of Children in the Provinces', in Greece \& Rome 57, no. 1 (2010), 117-21, esp. 117-18.

62 Scheid, 'Graeco-Roman Cultic Societies', 541-42.

63 Cornelia B. Horn and John W. Martens, Let the Little Children Come to Me: Childhood and Children in Early Christianity (Washington, DC: Catholic University of America, 2009), 33; Mantle, 'Roles of Children in Roman Religion', 100-2.

64 Wiedemann, Adults and Children, 181.

65 Albert Henrichs, 'Changing Dionysaid Identities', in Jewish and Christian SelfDefinition, Vol. 3: Self-Definition in the Graeco-Roman World, ed. Ben F. Meyer and E. P. Sanders (Philadelphia, PA: Fortress, 1983), 3:137-60, esp. 3:140, 141, 148-50.

66 Wiedemann, Adults and Children, 186.

67 Horn and Martens, Let the Children, 187-88. 
infants or young children. Considered together, what we find is that practices and expectations for the initiation and participation of young children varied between different voluntary religious assemblies. Whether a particular set of expectations or practices was dominant is unclear, though it does seem unlikely that infant initiation was the norm among voluntary assemblies and cults at this time.

\section{d. Insights on the Place of Children by Considering Graeco-Roman Parenting}

It is also helpful to think of the Graeco-Roman view of childrearing. The goal in raising children was to instill an ethic that 'was, quite openly, one of obedience and docility'. ${ }^{68}$ In light of this it seems unlikely that, without specific instructions, converts to the church from the Graeco-Roman world would have placed a high value on a child's 'choice' of religion (and hold Christian initiation off until then) rather than valuing their submission to the family religion. ${ }^{69}$

\section{e. What Kind of Religion was the Church?}

Having considered the three major categories of religions in the Graeco-Roman world (civic/imperial, family, voluntary associations), we now must ask which category a Graeco-Roman convert would have put the Christian church in. This will help us determine which set of presuppositions a convert would have carried with him into the church.

N. T. Wright makes a strong argument that the Apostle Paul's gospel was aimed at the imperial cult of Caesar and placed itself in the same category, making them rivals. Paul's use of the word 'gospel' (euangelion) would have been associated with the birth of a new emperor, and in the context of the Roman Empire it would have been heard as a summons to another king, of which Paul claimed to be an ambassador. Paul's identifying Jesus as lord (kyrios) would have been seen as a challenge not primarily to private mystery religions, but to the lordship of Caesar. Wright argues that by giving Jesus the titles he does in Philippians 3, and by casting the Philippian church as an outpost of heaven instead of Philippi as an outpost of Rome, Paul is arguing that Jesus is lord and Caesar is not. Wright concludes that 'religion' is too

68 Aline Rousselle, Porneia: On Desire and the Body in Antiquity, trans. Felicia Pheasant (Oxford: Blackwell, 1988), 54.

69 Cf. Mark Searle, 'Infant Baptism Reconsidered', in Living Water Sealing Spirit: Readings on Christian Initiation, ed. Maxwell E. Johnson (Collegeville, MN: Liturgical, 1995), 365-409, esp. 367. 
restrictive a category for Paul's message, but that it is a joining of religion and politics, in the same category as the Caesar cult. ${ }^{70}$

As some have critiqued Wright's larger arguments concerning Paul's gospel and the Roman Empire, ${ }^{71}$ it is important to clarify that this paper is merely arguing for categorical proximity between Paul's gospel and the imperial cult, and not that Paul's gospel was centrally concerned with Rome itself or with political revolution. Critics of Wright have themselves noted the distinction between claiming that Paul's gospel was 'in deliberate antithesis to the imperial gospel' versus 'attempting to read Paul's teaching as anti-imperial'. ${ }^{72}$ For our purposes, we are not arguing the latter, and only looking to a softer version of the former: our claim is merely that for Gentiles converting to Christianity and entering the church in the first century, the closest category that would exist in their minds for understanding the church and its faith was the Caesar cult, and Paul's language reflects and affirms that categorical proximity, even 'evoking a comparison' between Christ and Caesar. ${ }^{73}$

That the contemporaries of Paul (Acts 17:6-7) and even of Jesus (John 19:12-16, Luke 23:2) could plausibly portray Christ's gospel as a challenge to Caesar would also seem to support the idea that in firstcentury minds, Christ's gospel had categorical proximity to Caesar's cult. This would also help explain why Celsus later criticised the early church for being a religious group that behaves like a nation. ${ }^{74}$

It is important to remember that one reason the early church faced persecution was their refusal to participate in the state religion and the imperial cult. Such a reason is given by Pliny the Younger (appointed governor of Bithynia in AD 111) and in Polycarp's martyrdom, but other emperors persecuted the church as early as AD 64. It appears that

70 N. T. Wright, 'Paul's Gospel and Caesar's Empire', in Paul and Politics: Ekklesia, Israel, Imperium, Interpretation: Essays in Honor of Krister Stendahl, ed. Richard A. Horsley (Harrisburg, PA: Trinity Press International, 2000), 160-83. For a more amusing presentation of a similar argument, see Peter J. Leithart, Against Christianity (Moscow, ID: Canon, 2003), 11-40.

71 E.g. Seyoon Kim, Christ and Caesar: The Gospel and the Roman Empire in the Writings of Paul and Luke (Grand Rapids, MI: Eerdmans, 2008).

72 Kim, Christ and Caesar, 7.

73 Kim, Christ and Caesar, 15.

74 R. Joseph Hoffmann, 'General Introduction', in Celsus, On the True Doctrine: A Discourse Against the Christians, trans. R. Joseph Hoffmann (New York: OUP, 1987), 1-45, esp. 34. 
emperors saw Christianity as a threat to the integrity of the state. ${ }^{75}$ All of this would support the idea that Christianity did not primarily fit in the category of a family cult or a voluntary assembly, but of a rival imperial cult, and was treated by the state as such. ${ }^{76}$

\section{Conclusions}

This paper, though technically a historical study, has in reality been about exegesis. Having acknowledged that taken by themselves, the texts of the New Testament are ambiguous regarding the baptism of infants, most debates have either ended in stalemates there, or have continued back and forth without finding any new points of traction. Others have left the New Testament text itself and have repositioned the debate within systematic or pastoral theology. The failure of these methods is that they interpret the silence of the New Testament in a vacuum. The text is treated as if it lacked an original presupposition pool, or far worse, it is read within our twenty-first-century, Western presupposition pool.

This study is essentially an attempt to force the question of infant baptism back to the New Testament text by providing a cultural context for the text in which its silence can be accurately interpreted. What we have found is that within its historical context, the silence of the New Testament regarding infant baptism points strongly in favour of a normative practice of baptising and fully initiating the infants of Christians into the church and the Christian faith.

In both the Jewish and the Graeco-Roman cultures surrounding the apostolic church we have found a consistent presupposition of the full

\footnotetext{
75 Justo L. González, The Story of Christianity, Vol. 1: The Early Church to the Dawn of the Reformation, 2nd ed. (New York: HarperOne, 2010), 43-58.

76 Against this, Joel B. Green has focused on the family-centered nature of early Christianity (like the family cult) and Philip A. Harland and Richard S. Ascough have argued for similarities between early Christianity and voluntary associations. Their arguments are ultimately not as convincing as N. T. Wright's. Though they are deserving of more interaction, it is beyond the scope of this paper (Joel B. Green, 'She and Her Household were Baptized (Acts 16.15): Household Baptism in the Acts of the Apostles', in Dimensions of Baptism: Biblical and Theological Studies, ed. Stanley E. Porter and Anthony R. Cross (London: Sheffield Academic, 2002), 72-90; Philip A. Harland, Associations, Synagogues, and Congregations: Claiming a Place in Ancient Mediterranean Society (Minneapolis, MN: Fortress, 2003), 29, 31, 40-41; Richard S. Ascough, 'The Thessalonian Christian Community as a Professional Voluntary Association', in Journal of Biblical Literature, 119, no. 2 (Summer 2000), 311-28).
} 
initiation of infants based on the religious status of their parents. If our interpretation of the above data is correct, then all new converts entering the Christian church, whether from a Jewish or a GraecoRoman background, would have expected their infants to be initiated into their religion within the first weeks of life. Yet in the New Testament and in the surviving documents from the first two centuries of the church, we do not see this presupposition opposed, challenged, or even taken up from the presupposition pool to be discussed. The church's silence on the issue of infant initiation within such a context makes the possibility that the early church either did not initiate infants or only partially initiated infants highly unlikely. Such a practice would have been in opposition to the presuppositions of all new converts to the church. That there would be no surviving discussion, instruction, or debate if the church barred infants from initiation is difficult to believe.

Anyone arguing that the apostolic church did not baptise infants would have to make some difficult historical claims. They would need to claim that the apostolic church did something foreign to the presuppositions of all its new converts, but that this very unique practice was introduced and implemented without any surviving record of discussion, debate, confusion, or instruction. Additionally, they would need to say that the apostolic church developed (unique from other surrounding religions) a catechetical pattern and a process of baptismal admission for children of Christians as they grew up, but without any record of that process, or debate about a minimum age for baptism, surviving. Such a case becomes challenging to believe.

This paper makes no claim of solving the question of infant baptism in the early church. It is instead intended to be a step in the overall process. Yet from this study we can say that the scenario that best fits with the presupposition pool within which the New Testament was written and read, is that the early church did fully initiate the infants of Christians through baptism. 